\title{
PARENTAL ACCESS TO MINORS' HEALTH RECORDS IN THE SOUTH AFRICAN HEALTH CARE CONTEXT: CONCERNS AND RECOMMENDATIONS
}

MN Slabbert*

\section{Introduction}

Medical records have evolved over time into much more than merely a doctor's aide-mémoire as they were originally intended. Medical records are an invaluable tool in patient care and also a valuable resource that may be used to inform health care planning and financial audit, epidemiological research, education, to name but a few. More people than ever before have access to patients' records and put them to uses that most patients are most likely unaware of. ${ }^{1}$ This has led to concern over the security and use of patient information contained in medical records, whether hand-written or electronically stored. A person's health, on the other hand, is essentially a very private matter and unauthorised disclosures of one's health information may cause irreparable harm. The tension between these two goals, namely patient privacy on the one hand and access to information on the other, has recently been heightened by the transition to electronic health information in support of health care delivery and health data networks. ${ }^{2}$ Many countries have now promulgated legislation and other measures to regulate access of persons and institutions to health and other kinds of data records. ${ }^{3}$ In

* MA, DLitt (UP), LLB, LLD (Unisa). Associate Professor, School of Law, Department of Jurisprudence, University of South Africa. The article is an extended version of a paper delivered on 4 August 2004 at the $15^{\text {th }}$ World Congress on Medical Law, held in Sydney, Australia, from 1-5 August.

1 Tingle Patient confidentiality 83.

2 See SALR Privacy and Data Protection 88.

3 In the UK, the Data Protection Act 1998 provides a complete framework for the regulation and processing of all forms of data. In Canada the Privacy Act 1983 and Personal Information Protection and Electronic Documents Act 2000 provide similar protection. In Australia access to and the protection of personal information are regulated by the Privacy Act 1988 and the Privacy Amendment (Private Sector) Act 2000, and in New Zealand these are governed by the Privacy Act 1993. 
August 2003, the South African Law Commission released an issue paper on privacy and data protection. ${ }^{4}$ One of the specific areas of concern noted in this issue paper is the domain of health. ${ }^{5}$ It is indeed troublesome that there is at present in South Africa no consistency in approaches to patient confidentiality in general, nor any national standards or policies on patient confidentiality. ${ }^{6}$ The general constitutional provisions relating to privacy and access to information are inadequate in dealing with the specifics of the doctor-patient relationship.

In South Africa, the medical practitioner's duty to maintain confidentiality concerning his or her patient is both an ethical ${ }^{7}$ and a legal duty. ${ }^{8}$ What is less clear is whether this duty is also owed to minor patients. A dilemma arises when the parents of a minor patient approach a doctor to enquire about their child's medical treatment, particularly if the minor has expressly requested that the contents of his or her medical records not be divulged to his or her parents. Minors may wish to prevent their parents from accessing their medical records that may contain details about sexually transmittable diseases, contraception, abortion, depression, alcoholism, smoking or drug habits, or whatever the case may be. Parents, on the other hand, may insist on knowing what is happening in their children's lives as a matter of concern for their children's welfare and in order to take care of them properly.

This dilemma poses intricate questions that do no always have straightforward

\footnotetext{
4 See $\mathrm{n} 2$ above.

5 SALC Privacy and Data Protection 133.

6 SALC Privacy and Data Protection 135.

7 Respecting the confidences of his or her patient is one of the most fundamental ethical obligations owed by a doctor to his or her patient. The Hippocratic Oath in this respect states: "Whatsoever things I see or hear concerning the life of men, in my attendance on the sick or even apart there from, which ought not to be noised abroad, I will keep silence thereon, counting such things to be as sacred secrets." See Kennedy and Grubb Medical law 1047.

8 See Jansen van Vuuren v Kruger 1993 (4) SA 842 (A). In this case, the doctor's duty of confidentiality towards his patient who suffered from AIDS, was recognised. This ruling makes it clear that medical confidentiality is not merely a matter of professional ethics, but also a legal duty, the breach whereof may result in legal liability.
} 
answers. Consider, for example, the following example cited by Richardson ${ }^{9}$ showing how confidentiality may compete with other interests: The parents of Alex, a fifteen year old boy who is a haemophiliac, refuse to tell him that he is HIV positive as the result of earlier blood transfusions. Alex, on the other hand, is keeping secret from them the fact that he is engaging in unprotected sexual activities. He confides in a nurse, because he is worried about suffering from a venereal disease. The nurse is in possession of both sets of information: the boy does not want his parents to be informed of his sexual activities, and the parents do not want their son informed about his HIV status.

In South Africa, the legal position relating to the confidentiality of minors' health records has become more obscured than ever with the promulgation of the Promotion of Access to Information Act ${ }^{10}$ which, against the background of the common law and constitutional protection of privacy and read together with both the Children's Bill ${ }^{11}$ and the National Health Bill, ${ }^{12}$ sketches a conflicting picture. This paper will first, very briefly, explore the question whether a child is owed a duty of confidentiality, after which the confidentiality of health records will be discussed, in particular the question whether parents may access their minor children's health records without their consent.

\section{Should a child patient be owed a duty of confidentiality?}

Most children's first contact with health care providers ${ }^{13}$ takes place through their

9 Richardson and Webber Ethical issues ch 10.

10 Promotion of Access to Information Act 2 of 2000. (Hereinafter referred to as PATIA.)

11 Children's Bill [B70-2003]. This comprehensive bill, when enacted, will replace and repeal the whole of the Child Care Act 74 of 1983.

12 National Health Bill [B32-2003]. Some of the primary objects of the bill, when enacted, are to regulate national health and provide uniformity in respect of health services in South Africa by establishing a national health system and by setting out the rights and duties of health care providers, health workers etc.

13 The term "health care providers" is the preferred term, also referred to in the National Health Bill to include any person providing health services in terms of any law, including the Allied 
parents, themselves often patients of the relevant health care provider. After examining the minor patient, the health care provider-let's assume it is a medical practitioner-usually informs the parents of her findings in order for them to consent to further treatment and to enable them to carry out their duty to care for their child. Most doctors, unless specifically requested by minors, appear to accept that disclosure to the parents is in order, especially when the parents are the ones carrying the bill at the end of the day. The duty of confidentiality should, in principle, apply to all of a doctor's patients, regardless of age, yet no court has yet offered an analysis of why the child is or should be owed a duty of confidentiality. ${ }^{14}$ Is this a duty that flows from the doctor-patient relationship vis-àvis the child's parents or guardians, dictating that a duty of confidence is owed to the child, but that disclosures to the parents are in order whenever these fall within certain recognised exceptions justifying disclosure? Or is it a duty that only arises when the child reaches a certain intellectual and social maturity in order to form a meaningful relationship of confidence with the doctor, in other words when he or she has the capacity to grasp what secrecy entails?

The flipside of the coin also exists, namely whether the minor patient can claim a right to confidentiality. This question is narrowly intertwined with the equally important issue of consent to medical treatment in instances where the minor is still under parental authority. The well-known English decision by the House of Lords addressing a minor's right to confidentiality, Gillick $v$ West Norfolk and Wisbech Area Health Authority, ${ }^{15}$ offers interesting directions, but leaves many questions unanswered. ${ }^{16}$ The judgment establishes that a doctor indeed owes a mature minor patient a duty of confidentiality where the child is competent to form

Health Professions Act 63 of 1982; the Health Professions Act 56 of 1974; the Nursing Act 50 of 1978; the Pharmacy Act 53 of 1974; and the Dental Technicians Act 19 of 1979 (see cl $1)$.

14 Kennedy and Grubb Medical law 1077.

15 Gillick v West Norfolk and Wisbech Area Health Authority [1984] QB 581, [1984] 1 All ER 365; on appeal [198] AC 112, [1985] 1 All ER 533; rev [1986] AC 112, [1985] 3 All ER 402 $(\mathrm{HL})$.

16 The case is discussed by Morgan 1986 Monash University Law Review 161; Sir Wilson 1996 Australian Journal of Forensic Sciences 8; and Parkinson 1992 Australian Journal of 
a relationship of confidence, but that this is not absolute and will depend on the individual circumstances of the case. The decision has led to what can be termed the "mature minor" or "Gillick-competency" test: A minor under the age of 16 years (the statutory age for consenting to medical treatment in England) can consent to medical treatment when he or she has "sufficient understanding and intelligence to understand fully what is proposed". ${ }^{17}$ It follows that if a child may legally consent to medical treatment, he or she should also be able to consent to disclosures about his or her medical treatment to third parties. The mature minor test was approved by the Australian High Court as being in accordance with children's psychological development as described by Piaget who suggested that:

... the capacity to make an intelligent choice, involving the ability to consider different options and consequences, generally appears in a child somewhat between the ages of 11 and $14 .{ }^{18}$

Before closer attention is given to the patchwork of provisions in the South African law relating to the access of parents and third parties to the health records of minors, a brief overview of the legal position of the minor patient in South African law is necessary.

\section{The minor patient in South African law}

In the case of a minor under parental authority, the doctor would in principle require the consent of the minor's parent or legally appointed guardian for medical treatment. ${ }^{19}$ Parental authority refers to a number of rights and duties that vest in a parent, or occasionally in a non-parent, in respect of the person and

Family Law 101.

17 Gillick v West Norfolk [1986] AC $112(\mathrm{HL}) 189$ per Lord Scarman.

18 Department of Health and Community Services v JWB (Marion's case) (1992) 175 CLR 218; 106 ALR 385 (HCA) at CLR 237-238; ALR 395.

19 See Esterhuizen v Administrator, Transvaal 1957 (3) SA 710 (T). 
estate of a minor child. Parental authority must at all times be exercised and performed in the minor' best interests, as well as with due regard to the minor' rights. ${ }^{20}$ In cases where parental consent or consent from a legal guardian cannot be obtained, the High Court as the upper guardian of all children can be approached to provide consent. In South African law, the present statutory age for independent consent to medical treatment as set out in the Child Care $\mathrm{Act}^{21}$ is 14 years, whereas a minor who is eighteen years or older, may independently consent to a medical operation. ${ }^{22}$ For children under the age of fourteen where the consent of a parent or guardian cannot be obtained, permission for a medical procedure may be sought from the Minister of Social Development. ${ }^{23}$ The legislature has refrained from defining the phrase "medical treatment" and "medical operation". A minor under the age of 14 seeking medical treatment (for example in the form of oral contraception or the insertion of a contraceptive device) may require the consent of her parent or guardian, because such minor is still subject to parental authority. ${ }^{24}$

The promulgation of the Choice on the Termination of Pregnancy $\mathrm{Act}^{25}$ has added an interesting twist to the above statutory regime. In terms of this act that regulates abortion, any female of any age $e^{26}$ may have her pregnancy lawfully terminated upon request during the first twelve weeks of the gestation period of her pregnancy. ${ }^{27}$ Where the pregnant woman is a minor, the medical professional concerned is only under an obligation to advise her to consult with her parents,

20 In Kaiser $v$ Chambers 19694 SA 224 (C) 228G, Tebbut aj (as he then was) described the child's best interests as "[a] golden thread which runs throughout the whole fabric of our law relating to children". S 28(2) of the Constitution of the Republic of South Africa 1996 enshrines the paramountcy of this consideration. No parental rights will be enforced if in conflict with the child's welfare. See in general B v S 1995 (3) SA 571 (A). The Children's Bill (above $n$ 11) refers to the term "parental responsibilities and rights" which are described as "the responsibility and right (a) to care for the child; (b) to have and maintain contact with the child; and (c) to act as the guardian of the child" (cl 1).

21 Child Care Act 74 of 1983.

22 Ibid s 39(4)(b).

23 Ibid s 39(1).

24 Gordon v Barnard 1977 (1) SA 887 (C); H v I 1985 (3) SA 237 (C).

25 Choice on the Termination of Pregnancy Act 92 of 1996.

26 See s 1(xi): "Woman" is defined as any female person of any age. 
guardian, family or friends before the pregnancy is terminated. The termination may not be denied should she choose not to consult with such persons. ${ }^{28}$ Despite the fact that most of these first-trimester abortions do not involve any serious surgical intervention, it nevertheless creates an anomaly in the sense that a grave decision of this nature does not require any parental consent or guidance. A separate set of principles relating to the requirement of parental consent now applies in respect of the termination of pregnancies on the one hand, and other medical interventions on the other. This absurd result in practice requires the consent of the parents of a sixteen-year old minor under parental authority for the removal of her tonsils, but not when she decides to end her pregnancy and have an eleven-week old foetus removed from her womb!

The Children's Bill, ${ }^{29}$ set to repeal the whole of the Children's Act, ${ }^{30}$ the Child Care $A c t^{31}$ and the Guardianship Act, ${ }^{32}$ provides for the independent medical decision-making of a child in certain circumstances. ${ }^{33}$ The Bill provides that a child may be subjected to medical treatment or a surgical operation only if consent is given in terms specific provisions of the Bill. ${ }^{34}$ A child may consent to medical treatment or a surgical operation provided that the child is at least 12 years old and is of sufficient maturity and has the mental capacity to understand the benefits, risks, social and other implications of the treatment or operation. ${ }^{35}$ The latter allowance is however qualified in the same subsection that states that

27 S 2(1)(a).

28 S 5(4) and (5) make special provision for terminations in respect of women who are severely mentally disabled or in a state of continuous unconsciousness.

29 Above $\mathrm{n} 11$.

30 Children's Act 33 of 1960.

31 Above $\mathrm{n} 21$.

32 Guardianship Act 192 of 1993.

33 "Child" is defined as a person under the age of 18 years. The Children's Bill, initially submitted to Parliament dealt with the full spectrum of the protection of children on both national and provincial level was later found to be a "mixed" bill containing elements to be handled in terms of both s 75 (functional area of national legislative competence) and s 76 of the Constitution and was consequently split. Children's medical decision-making now falls under matters that apply to the provincial government only and will be introduced as a Children's Amendment Bill as soon as the s 75 Children's Bill has been enacted.

$34 \mathrm{Cl}$ 129(1) of the consolidated bill, dated 12 August 2003. The consent may be given only in terms of cl 129, subs (2), (3), (4) or (5). 
such a child may not consent to a surgical operation without the assistance of either the parent of the child or the primary care-giver of the child. ${ }^{36}$ The requirement of parental assistance ${ }^{37}$ for surgical operations in the absence of a clear definition of "assistance" is difficult to grasp: Does it in addition refer to parental advice or supplementary support, ${ }^{38}$ or does it entail parental approval? As far as assisting a child in this regard is concerned, the Bill states that no parent or primary care-giver may refuse to assist a child in consenting to a surgical operation by reason only of religious or other beliefs. ${ }^{39}$ The position of a child whose parent or care-giver refuses to assist is also unclear. Would such a child's consent be valid in the absence of the required assistance? For children under the age of 12 years, or children over the age of 12 lacking the maturity or mental capacity to understand the benefits, risks and social implications of the treatment or operation, the parent or primary care-giver may consent to medical treatment or a surgical operation. ${ }^{40}$ The Bill also provides for consent given by the superintendent or the person in charge of a hospital, as well as the High Court or the children's court in certain instances. ${ }^{41}$ In the case of HIV-testing, the Bill states that a child below the age of 12 years and of sufficient maturity to understand the implications of such a test may consent to an HIV-test. ${ }^{42}$ The Bill also provides that every child has the right to confidentiality regarding his or her health status and the health status of a parent, care-giver or family member, except when maintaining such confidentiality is not in the particular child's best interests. ${ }^{43}$

$35 \mathrm{Cl}$ 129(2)(a).

$36 \mathrm{Cl}$ 129(2)(b).

37 Or assistance given by the child's primary care-giver in terms of $\mathrm{cl}$ 129(2)(b)(ii).

38 See Merriam-Webster http://www.m-w.com/ 8 Sep 2004. Under "assistance": to give support or aid; to be present as spectator.

$39 \mathrm{Cl}$ 129(6). The same provision states that consent may be refused if a parent or primary care-giver can show that there is a medically accepted alternative choice to the medical treatment or surgical operation concerned.

$40 \mathrm{Cl} 129(3)$.

41 Clauses 129(4) and 129(5).

$42 \mathrm{Cl}$ 130(2).

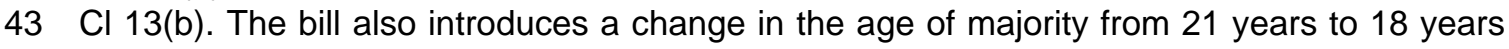
(cl 17). 
The above developments, necessitated by the large number of children requiring medical assistance as a result of HIVIAIDS and violence, are welcomed. The present provisions relating to consent entrenched in the Child Care Act instead of protecting children pose serious barriers to protecting their rights to life and to the highest attainable standard of health under the Constitution. ${ }^{44}$ The logical consequence of these new provisions, read together with the provision relating to confidentiality, is that a minor over the age of twelve years will also be able to consent to disclosures of his or her medical records. Health care practitioners may be justified for breaching this confidentiality (for example by disclosing any medical facts about his or her patient to any third party) if the patient expressly or impliedly ${ }^{45}$ consents to the disclosure ${ }^{46}$ if the comprehensive care of a patient requires other health care providers to have access to confidential information; ${ }^{47}$ if the health care provider is engaged by an employer, insurance company or other third party to report on a patient; ${ }^{48}$ if required by statute to disclose certain information in the public interest; ${ }^{49}$ and if ordered by a competent court to disclose certain information for the purposes of medical negligence suits ${ }^{50}$ or criminal prosecutions.

44 S 28(1). Cf Gerntholtz and Schleifer Aidslaw project 3. The submission refers to research which has shown that problems in obtaining consent on behalf of unaccompanied children and those whose parents or guardians refused to consent to medical treatment barred some children from receiving post-rape medical services (at 5).

45 An example of implied consent arises, for example, where a doctor who refers a patient to a specialist for treatment or advice will send the specialist information about the patient's condition. A doctor's prescription similarly tells the pharmacist something about the patient's condition.

46 The National Health Bill [B32-2003] also lists the patient's ("user's") consent as an exception (cl 14(2)(a)).

47 The patient's authorisation for this is either direct (the patient's signature to a hospital consent form agreeing that hospital staff may examine him or her and his or her records), or implied (when the patient seeks treatment in a hospital).

48 The legal justification for the doctor disclosing the information is the patient's express or implied consent. The doctor and third party are both bound by the confidentiality to the extent that they may use and impart the information only for the purpose intended.

49 Doctors are usually required to inform government health authorities of patients with certain infectious or notifiable and sexually transmitted diseases; and give notification of abortions performed. The National Health Bill provides that the disclosure of personal information will be justified when "non-disclosure of the information represents a serious threat to public health" (cl 14(2)(c)).

50 This exception is recognised in $\mathrm{cl} 14(2)(\mathrm{b})$ of the National Health Bill. 
In South Africa, the position regarding access to the medical records of minors does not appear to correspond to the developments relating to minors' consent to medical treatment and surgical operations.

\section{Access to and disclosure of information contained in health records}

Unlike in many other Western legal systems, specific measures for the protection of data pertaining to individuals have not yet been enacted in South Africa. In terms of the recent Promotion of Access to Information Act, ${ }^{51}$ personal information should be accessible to the individual to whom it relates. ${ }^{52}$ This Act gives effect to the public's right of access to information from public and private bodies, as contained in section 32 of the Constitution, ${ }^{53}$ but must be read with existing legislation and regulations which deal specifically with the right to and the provision of information, as well as existing legislation and regulations dealing specifically with the retention of information. ${ }^{54}$ Until such time as separate and specific legislation for the protection of privacy and data is promulgated, measures contained in the Promotion of Access to Information Act protecting the right to privacy are being regarded as interim measures.

Freedom of information and privacy are closely related. The collection and

51 Promotion of Access to Information Act 2 of 2002, s 88. For the history and background of the act, see Currie and Klaaren Commentary 1-11.

52 The act's main operative provisions protecting the right to privacy are the personal information grounds of refusal contained in s 34 and 63.

53 S 32 of the Constitution provides that everyone has the right of access to any information held by the state and any information that is held by another person and that is required for the exercise or protection of any rights. In addition, the Electronic Communications and Transactions Act 25 of 2002 provides for interim measures dealing with the correction of data and the voluntary adherence to data protection principles.

54 Eg relating to the disclosure of information, the Banks Act 94 of 1990 (GN R.1112 of 8 November 2000); Companies Act 61 of 1973 (eg s 237-239); Income Tax Act 58 of 1962 (s 4); Occupational Health and Safety Act 85 of 1993 (s 36), to name but a few. For provisions relating to the retention of records, eg the Basic Conditions of Employment Act 75 of 1997 (s 31); Close Corporations Act 69 of 1984 (s 13-14); Insolvency Act 24 of 1936 (s 134, 155); and the Value-Added Tax Act 89 of 1991 (s 55). 
dissemination of personal information by both public and private bodies on the one hand must be balanced on the other hand by the rights of individuals to know who has information about them, what the contents of this information are, as well as the right to be able to correct or amend inaccurate, misleading or outdated information. The general right to privacy that is given effect to in the Promotion of Access to Information Act has been interpreted by the Constitutional Court as extending only to those parts of one's life in respect of which one has a legitimate expectation of privacy. ${ }^{55}$

The right to privacy is protected in terms of our common law and the Bill of Rights. ${ }^{56}$ Both the fundamental right to privacy entrenched in the Constitution, as well as the common law protection of privacy, do not offer absolute protection and may be limited in terms of a law of general application ${ }^{57}$ and has to be balanced with other rights entrenched in the Constitution.

As far as private information is concerned, there is a reasonable expectation that privacy will be recognised. ${ }^{58}$ The general right to privacy in the freedom-of-

55 Investigating Directorate: Serious Economic Offences v Hyundai Motor Distributors 2001 (1) SA 545 (CC) par 16: "Wherever a person has the ability to decide what he or she wishes to disclose to the public and the expectation that such a decision will be respected is reasonable, the right to privacy will come into play."

56 The common law protects every person's personality rights such as the right to dignity, good name and bodily integrity. The common law protects rights of personality under the action iniuriarum. See Stoffberg v Elliot 1923 CPD 148; Lymbery v Jefferies 1925 AD 235; Lampert $v$ Hefer 1955 (2) SA 507 (A); Esterhuizen v Administrator, Transvaal 1957 (3) SA 710 (T). Cf Neethling, Potgieter and Visser Law of personality 38. S 14 of the Constitution states that everyone has the right to privacy, which includes the right not to have- (a) their person or home searched; (b) their property searched; (c) their possessions seized; or (d) the privacy of their communications infringed.

57 S 36 of the Constitution describes how rights may be limited. Other constitutional rights may also limit the right to privacy, such as, eg the right to access to information (s 32) and right to freedom of expression (s 16). Privacy as a common law right of personality will necessarily be limited by the interests of others, as well as the public interest.

58 A violation of privacy in respect of private data would necessarily involve the possible disclosure or release of private information relating to personal or intimate aspects of a person's life; that the data was provided for one purpose, but was used for another; or that it was disseminated to the general public, press or other third parties from whom one could reasonably expect that the disclosure would have been withheld. These factors were considered important by the Constitutional Court in establishing whether a violation of the right to privacy of private information took place in Mistry $v$ Interim National Medical and 
information context encompasses two specific concerns: an interest described as "informational self-determination" ${ }^{59}$ restricting the use, collection and disclosure of private information, and an interest in accessing personal information that has been collected by others in order to ascertain its content and check its accuracy. ${ }^{60}$ Although the Promotion of Access to Information Act protects both interests to some degree, it is primarily concerned with regulating the use, collection and disclosure of private information. This is achieved by virtue of two provisions of the act ${ }^{61}$ that prevent the use of the right access to information to obtain personal information about a third party.

Normally, in respect of a doctor-patient relationship, the unauthorised disclosure of private medical facts contained in a health record held by a private medical practitioner to a third party will, as a breach of confidentiality, be prima facie wrongful and an infringement of the right to privacy. ${ }^{62}$ The question arises whether the Promotion of Access to Information Act makes provision for third parties, such as parents, to request access to the health records of their minor children, and to what extent the Act protects the privacy of minors' health records.

The Promotion of Access to Information Act (hereafter the "PATIA") regulates both privately and publicly held information and overrides other legislation in respect of access to information. The PATIA does not contain a general

Dental Council of South Africa 1998 (4) SA 1127 (CC) par 51.

59 This term originates from the term "informationelle Selbstbestimmung" used by the German Constitutional Court in its Census decision, 65 BVerfGE 1 (1983).

60 Currie and Klaaren Commentary 119.

61 S 34 and 63 of the act.

62 As a possible infringement of the constitutional right to privacy or the common law of privacy, which will depend on the individual facts of each case. In the case of common law protection, the remedy will lie in the recovery of damages, whereas the constitutional remedy would involve the acknowledgement and enforcement of a fundamental right. The constitutional inquiry into whether the right to privacy has been infringed would entail an enquiry whether the right has been infringed and whether the infringement is justified, as opposed to the common law exercise as to whether there has been an unlawful infringement of one of the rights of personality. See in particular Jansen van Vuuren $v$ Kruger 1993 (4) SA $842(A) 850$. 
prohibition on the disclosure of certain categories of information and merely provides for certain mandatory grounds of non-disclosure relating to requests under the Act. A person is entitled to access the records of both public and private bodies if there is no ground upon which access to that record can be refused in terms of the Act. ${ }^{63}$ As far as public bodies are concerned, a person requesting access to information held by public bodies is entitled to access, irrespective of his or her reasons for requesting access, ${ }^{64}$ but when a private body is approached for access, the record has to be required for the exercise or protection of rights. One of the grounds upon which access to records must be refused $^{65}$ is when a request for information would involve the unreasonable disclosure of personal information ${ }^{66}$ about a third party; ${ }^{67}$ if the disclosure would constitute an action for breach of a duty of confidence owed to a third party in terms of an agreement, ${ }^{68}$ and if the disclosure could reasonably be expected to endanger the life or physical safety of an individual. ${ }^{69}$ However, a number of exceptions to this rule are set out in the act of which some are briefly mentioned: when the third party has consented in writing to the disclosure, ${ }^{70}$ where the information is already publicly available ${ }^{71}$ and where the information concerns the physical or mental health or well-being of an individual who is under the care of the requester and who is under the age of 18 years or incapable of

\section{S 11(1).}

64 S 11(3).

65 In addition to the grounds on which a request for access must be refused, the PATIA provides for other grounds upon which a request for information may be refused (see $S$ 66(b), 68 and 69(2)).

$66 \mathrm{~S} 1$ of the PATIA defines "personal information" to include a variety of aspects, amongst others, a person's medical history.

67 S 34(1) in respect of information held by public bodies and s 63(1) in respect of information held by private bodies.

68 S 65. Part of the doctor-patient relationship is the expectation that the doctor will provide medical treatment and that the patient will furnish certain information about himself in order to receive the best possible treatment. Any unauthorised disclosure of confidential information relating to the patient will constitute a breach of this duty of confidence owed to the patient in terms of the agreement between doctor and patient.

69 S 66(a).

70 S 34(2)(a) in respect of information held by public bodies; s 63(2)(a) in respect of privately held information. The National Health Bill also recognises, in cl 14(2), the patient's ("user's") consent as an exception to the duty to maintain confidentiality.

71 S 34(2)(c) in respect of information held by public bodies; $S$ 63(2)(b) in respect of privately 
understanding the nature of the request and if giving access would be in the individual's best interests. ${ }^{72}$ This last-mentioned exception can be interpreted to include parental access to an 18 year old and younger child's file under any circumstance, provided that it is not unreasonable ${ }^{73}$ and if disclosure would be in the child's best interests. The PATIA only prohibits the "unreasonable" disclosure of personal information. The disclosure of personal information that violates the right to privacy will undoubtedly be unreasonable. It is conceivable; however, that some health care providers would not regard the disclosure of a minor's personal health information to his or her parents or guardian as "unreasonable". Such determination would hinge on a balance of two important interests: the interest in the protection of confidential information on the one hand, and the right of parents to access their child's medical records in order to exercise their parental authority and rights in respect of their minor child effectively on the other hand, which, in a paternalistic health care context, may tend to favour parental authority. The PATIA also does not provide for instances when a dispute between family members arises as to whether a file should be accessed or kept confidential. ${ }^{74}$

When one looks at the National Health Bill, an equally ambiguous picture emerges. The National Health Bill provides that every "user" is entitled to confidentiality of

... all information concerning a user, including information relating to his or her health status, treatment or stay in a health establishment. ${ }^{75}$

held information.

72 S 34(2)(d) in respect of publicly held information; s 63(2)(d) in respect of privately held information.

73 See n 66 above.

74 See Klinck (legal adviser of the Human Rights, Law and Ethics Unit, SAMA), in a letter to the Department of Justice dated 26 November 2001, cited in SALC Privacy and Data Protection 109 above $n 2$.

$75 \mathrm{Cl}$ 14(1). A "health establishment" means any public or private facility at which any health service is provided, excluding a military health establishment ( $\mathrm{Cl} 1)$. 
No person may disclose any information concerning a "user"76 unless the user consents to the disclosure; when disclosure is required in terms of a court order or any law; or when the non-disclosure would pose a serious threat to public health. ${ }^{77}$ The bill also provides for access to health records of users by health care workers or persons working for or on behalf of health establishments and the disclosure of personal information of such users

... to any other person, health care provider or health establishment is necessary for any legitimate purpose within the ordinary course and scope of his or her duties where such access or disclosure is in the interests of the user. ${ }^{78}$

The curious definition of "user", ${ }^{79}$ read together with the clause providing for access to health records, ${ }^{80}$ makes it clear that although the confidentiality of "users" (parents or guardians of minor patients included) is protected, disclosure of personal information by health care providers, such as medical doctors, to the parents of minors will be justified if this is necessary and takes place in the ordinary course of their duties and the disclosure is in the interests of the minor user. The National Health Bill also does not require a person who may lawfully give consent in terms of section 39(4) of the Child Care Act to treatment of or surgical intervention on a child, to consult with that child before information

76 The National Health Bill defines "user" as "the person receiving treatment in a health establishment, including receiving blood or blood products, or using a health service, and if the person receiving treatment or using a health service is -(a) below the age contemplated in s 39(4) of the Child Care Act 1983, ... 'user' includes the person's parent or guardian or another person authorised by law to act on the firstmentioned person's behalf; or (b) incapable of taking decisions, 'user' includes the person's spouse or partner, the person's parent, adult child or brother or sister, or another person authorised by law to act on the firstmentioned person's behalf". In view of the fact that the Child Care Act referred to in this clause is set to be repealed as a whole by the Children's Bill, when enacted, it is assumed that this reference will be rephrased.

$77 \mathrm{Cl} 14(2)$.

$78 \mathrm{Cl}$ 15(1). "Personal information" is defined to have the same meaning as "personal information" in PATIA s 1.

79 See $n 76$ above. If a child is below the ages stated in s 39(4) of the Child Care Act (eg 14 and 18), then "user" includes the parents or guardian of such a child. The definition of "user" is not clear as it appears that both the child and the parents or guardian are recognised as "users", though it is the child who is receiving the treatment and not its parents or guardian.

80 See $\mathrm{n} 78$ above. 
regarding his or her health status is disclosed.

\section{Conclusion}

It is submitted that the above ad hoc provisions relating to the confidentiality of children's medical records are still inadequate in protecting the minor's right to privacy. Although the Children's Bill includes a provision that children have the right to confidentiality regarding their health status, it appears that parents and guardians are able to access minor's health records in terms of both the Promotion of Access to Information Act and the National Health Bill. The statutory discrepancies identified above can be overcome in the following manner:

- The provisions in the Children's Bill relating to children's consent to medical treatment and surgical operation should spell out more clearly the requirement of a parent's or primary care giver's assistance in respect of a child's consent to surgical operations is concerned. The present formulation suggests that a parent or care-giver's consent is still required for surgical operations. It is also not clear what the result would be if a parent should refuse to render the required "assistance".

- The National Health Bill should mirror the provisions contained in the Children's Bill providing for children's autonomous medical decision-making in order to remove any uncertainty that may arise in respect of related confidentiality issues. Although a minor's confidentiality of health information appears to be protected, disclosures "in the interests of a user" in a paternalistic medical setting may favour parental access over a child's right to confidentiality in his or her health records. 
- Any proposed privacy and data protection legislation ${ }^{81}$ should include an explicit provision recognising a 12 year old and older child's right to confidentiality of personal information, subject to the limited number of recognised grounds justifying disclosure referred to above. ${ }^{82}$ The National Health Bill should also be amended to give effect to this in a similar way as the Children's Bill. The PATIA, in addition, should be amended by deleting the conflicting provision allowing access to information concerning the physical or mental health or well-being of persons under the age of 18 years under the care of the requester of the information. ${ }^{83}$

Children of 12 years and older consenting to medical treatment should be able to control parental access to their health records. The assumption for many years that parental authority over a child entitles a parent to automatic access of his or her minor child's health records can simply no longer be accepted. The time has come that parental access to minors' medical records in the South African health care context are once and for all clearly spelled out.

81 Investigated as an option by the SALR Privacy and Data Protection 4.

82 See par 3 above, text to $n$ 42-47.

83 See par 4 above, $\mathrm{n} 72$. 


\section{Bibliography}

Currie and Klaaren Commentary

Currie I and Klaaren J The Promotion of Access to Information Act: Commentary (Siberink Cape Town 2002)

Gerntholtz and Schleifer Aidslaw

Gerntholtz $L$ and Schleifer R Aidslaw project (Centre for Applied Legal Studies: Submission on the Children's Bill) 27 July 2003

Kennedy and Grubb Medical law Kennedy I and Grubb A Medical law $3^{\text {rd }}$ ed (Butterworths London 2000)

Morgan 1986 Monash University Law Review Morgan J "Controlling minors' fertility" 1986 (12) Monash University Law Review 161

Neethling, Potgieter and Visser Law of personality Neethling J, Potgieter JM and Visser P Neethlings law of personality (Butterworths Durban 1996)

Parkinson 1992 Australian Journal of Family Law

Parkinson P "Children's rights and doctors' immunities" 1992 (6) Australian Journal of Family Law 101

Richardson and Webber Ethical issues

Richardson J and Webber I Ethical issues in child health care (Mosby London 1995)

SALR Privacy and Data Protection

South African Law Reform Commission Privacy and Data Protection 
(Issue paper 24 Project 124) 28 August 2003

Tingle Patient confidentiality

Tingle J Patient confidentiality (Emis Professional Publishing Hertfordshire 2002)

Wilson 1996 Australian Journal of Forensic Sciences

Wilson R Sir "The Gillick Crusade" 1996 (19) Australian Journal of

Forensic Sciences 8

\section{Register of Statutes}

\section{Australia}

Privacy Act 1988

Privacy Amendment (Private Sector) Act 2000

\section{Canada}

Privacy Act 1983

Personal Information Protection and Electronic Documents Act 2000

\section{New Zealand}

Privacy Act 1993

\section{South Africa}

Allied Health Professions Act 63 of 1982

Banks Act 94 of 1990

Basic Conditions of Employment Act 75 of 1997

Child Care Act 74 of 1983

Children's Act 33 of 1960.

Children's Bill [B70-2003]

Choice on the Termination of Pregnancy Act 92 of 1996

Close Corporations Act 69 of 1984

Companies Act 61 of 1973

Constitution of the Republic of South Africa 1996

Dental Technicians Act 19 of 1979

Electronic Communications and Transactions Act 25 of 2002 
Guardianship Act 192 of 1993

Health Professions Act 56 of 1974

Income Tax Act 58 of 1962

Insolvency Act 24 of 1936

National Health Bill [B32-2003]

Nursing Act 50 of 1978

Occupational Health and Safety Act 85 of 1993

Pharmacy Act 53 of 1974

Promotion of Access to Information Act 2 of 2000

Promotion of Access to Information Act 2 of 2002

Value-Added Tax Act 89 of 1991

\section{United Kingdom}

Data Protection Act 1998

\section{Register of Cases}

B v S 1995 (3) SA 571 (A)

Department of Health and Community Services (NT) v JWB (Marion's case)

(1992) 175 CLR 218; 106 ALR 385 (HCA)

Esterhuizen v Administrator, Transvaal 1957 (3) SA 710 (T)

Gillick v West Norfolk and Wisbech Area Health Authority [1984] QB 581, [1984]

1 All ER 365; on appeal [198] AC 112, [1985] 1 All ER 533; rev [1986] AC

112, [1985] 3 All ER 402 (HL)

Gordon v Barnard 1977 (1) SA 887 (C)

H v I 1985 (3) SA 237 (C)

Investigating Directorate: Serious Economic Offences v Hyundai Motor

Distributors (Pty) Ltd 2001 (1) SA 545 (CC)

Jansen van Vuuren and Another NNO v Kruger 1993 (4) SA 842 (A)

Kaiser v Chambers 19694 SA 224 (C)

Lampert v Hefer 1955 (2) SA 507 (A)

Lymbery $v$ Jefferies 1925 AD 235 
Mistry v Interim National Medical and Dental Council of South Africa 1998 (4) SA 1127 (CC)

Stoffberg v Elliot 1923 CPD 148

Volkszählung 65 BVerfGE 1 (1983)

\section{Register of Internet resources}

Merriam-Webster http://www.m-w.com/ 8 Sep

Merriam-Webster "Online Dictionary" [Found on Internet] http://www.mw.com/ [Date of use 8 Sep 2004] 